DOI : $10.14746 / \mathrm{pp} .2015 .20 .4 .13$

\title{
Ferenc HÖRCHER
}

Budapest, Hungary

\section{Skinner and Rosanvallon: Reconciling the History of Political Thought with Political Philosophy*}

\begin{abstract}
This paper addresses the issue of whether a proper history of political thought should avoid any contact with substantive political philosophy, as it was vehemently claimed earlier by Cambridge historians of political thought, or not. It argues that (A) a strong political or philosophical bias might kill the credibility of a reliable history of political thought, but (B), in this genre, it is by definition impossible to avoid taking on board politico-philosophical concerns. What is more, the paper also tries to show (C) the relevance of political philosophy for the history of political thought and vice versa. In particular. it will argue along the following two lines: (a) Without a political philosophical self-positioning any reconstruction of the history of political thought remains underdetermined and therefore uninstructive, and (b) without a look at the history of political thought political philosophy remains blind, alienated. theoretically unfounded and therefore potentially even dangerous.

Methodologically, the paper aims to recapture some of the conclusions of the debates of the relationship of the two disciplines, with special attention to the French and British contexts (more particularly to the oeuvres of Rosanvallon and Skinner).
\end{abstract}

Key words: history of political thought, political philosophy, Skinner, Rosanvallon, Cambridge-school

\section{Introduction}

$\mathbf{T}$ b talk about politics has always been part and parcel of the European intellectual tradition. At least since Plato and Aristotle, there has been a continuous tradition of discussing politics within a theoretical framework, with far-sighted aims, besides the usual lip-service practiced among advisors of the powerful. However, there are different registers established for this discussion. These registers are dependent on the one hand on theoretical considerations and on the other, on the historically more accidental institutional structures of early modern and modern science, than on politics. Already, Aristotle made a clear-cut distinction between the profession of the historian and that of the poet and the philosopher in his Poetics (Aristotle, 1895, part IX). His distinguishing mark for history was to deal with the particular event, while philosophy and poetry provided the universal. There is no need to argue too long that philosophy seemed more valuable from this perspective than history writing. And yet historians played a major role in political regimes since Antiquity through the Middle Ages up to the Early Modern and Modern period. Their function was no less than legitimising the powerful. On the other hand, philosophy's aim was to confront politics with its own higher ideals elaborated over the centuries, but claimed to be independent from time and place.

*Artykuł został napisany w ramach projektu badawczego "Podstawowa literatura przedmiotu a kształt współczesnej politologii. Political science, Politische Wissenschaft i politologija w ujęciu porównawczym" (2012/05/B/HS5/00597), finansowanego przez Narodowe Centrum Nauki. 
It needed the forceful rhetoric of Machiavelli and the talent of his friend and critic Francesco Guicciardini to recontextualise the relationship of history and philosophy, in their competition for a priority in the discourse on government. Although heavily indebted to the ancient elaborations of the problem, these Florentine authors successfully showed that politics is an autonomous realm of human action with its own specific, universally valid but historically conditioned laws, and therefore that it requires a rather specialised discourse to talk about it in a valid fashion. In their descriptions they used historical narratives, or just simple events for illustrations of normative claims. In other words, in their way of writing, history and philosophy were not yet alienated from each other.

The modern mentality tried to pigeonhole these disciplines. First of all, it was the modern university (of science) that forced its requirement of professionalisation on writers of politics. While the $18^{\text {th }}$ century still witnessed the grandeur of universal (or philosophical) history writing (think of Voltaire, Hume or Gibbon), the Humboldt-style German university (and especially the newly founded Göttingen University) wanted to separate scientific research based on the research methodologies of the particular research fields. ${ }^{1}$ By distinguishing the science of politics from political history and the philosophy of politics, this era certainly did a lot to reshape human notions of politics, too (Iggers, 2011). Iggers refers to the birth of "historicism", this Germanic ideology of history, as the reason behind the academic breakthrough of history, and its positioning itself as the master science within the cosmos of university disciplines in the following way: the historical movement was "...substituting history for philosophy as the key to understanding things human" (Iggers, 2011, p. 41). One needs to understand, however, that behind this phenomenon there was a long and thrilling struggle between two paradigmatic forms of Weltanschaunng characteristic of late eighteenth and early nineteenth century German classical idealist philosophy: between different forms of Neo-Kantianism, acclaimed by their opponents to be ahistorical, and those of the Neo-Hegelian schools, with their special "sense of history".

To cut a long story short, it is to this Neo-Hegelian school, to which the so called Cambridge history of political thought can be traced back, through the first generation of British reception, including historians like Macaulay, Carlyle, Lord Acton and Maitland, and later $20^{\text {th }}$ century followers of it, including people like Collingwood, Hans Baron, Sir Herbert Butterfield and Peter Laslett. ${ }^{3}$

This description of the case is of course short-handed, and therefore unjust and certainly imprecise. ${ }^{4}$ The aim here was not to give a detailed history or historiography of the topic, but rather to show that the question at hand has a long and vexed history (and politics as well). In what follows we shall focus on the most recent developments in the debate. The paper will present as a starting point what might be called the separation thesis, which isolates the two twin disciplines of intellectual history and political philosophy,

${ }^{1}$ For a discussion of the connection between the classics of German Enlightenment and the birth of the historical movement, see Reill, 1975.

${ }^{2}$ See also Iggers, 1983.

${ }^{3}$ For a detailed analysis of how politics as a science developed in 19th century Britain, see Collini, Winch, Burrow, 1983.

${ }^{4}$ For a recent, volume-long analysis of the relationship of the history of political thought and political philosophy, see Floyd, Stears, 2011. 
represented by the position of the classical Cambridge historian, Quentin Skinner. Then the alternative "sister arts" position will be presented, both in its weaker and stronger forms. In the third part, an overall assessment of one key representative of the sister arts position will be provided, focusing on the oeuvre of Pierre Rosanvallon. As a conclusion, we shall see that even the classical Cambridge historians Quentin Skinner and J. G. A. Pocock have given up the ideal of a wholly autonomous art of history, and it will be asked what the rationality behind this turn is.

\section{The Separation Thesis}

In order to define the separation thesis, we need to see that the "scientific ideology" of the Cambridge-based history of political thought did not admit its own premises. According to Cambridge historians, there isn't and there has never been a Cambridge-school methodology in the history of political thought. What is more, they did not accept the label of Cambridge-school at all. Funnily enough, they were alone in this sort of rigour, all the professional world - except for them - shares the conviction that there is such a school with a wide-ranging impact, and that it has a very easily identifiable - if not methodology - then working strategy. The Cambridge Centre for Political Thought today writes on its introductory webpage: "Cambridge is a world-leading centre for the study of the History of Political Thought. Many of the subject's finest practitioners have studied and taught here, among them John Dunn, Duncan Forbes, Peter Laslett, John Pocock, Quentin Skinner, Gareth Stedman Jones and Richard Tuck." Presenting this short list of big names is, certainly, nothing less than admitting, or even more, proudly claiming Cambridge as a workshop, a school in the history of political thought.

If you take the typical overviews of the characteristic research style of Cambridge historians and their own reflections on their work so far, perhaps their most often repeated conviction is that if you want to study the history of political thought, you should avoid a typical mistake, which might probably be called the anachronistic fallacy. ${ }^{6}$ This fallacy consists of a typical mistake of historians, to interpret their past topic with the vocabulary of the present. This would cause the sort of anachronism which kills the historian's mission, which is to reconstruct the ideas of the past as they actually occurred.

Cambridge historians are typically characterised in the following way: "[i]n his most famous methodological piece, now more than three decades old, Skinner recommended a kind of enforced antiquarianism to keep presentist commitments from interfering with the intelligibility of texts, gained by restoring them to their place and time" (Moyn, 2006, p. 13). This "enforced antiquarianism" is the main reason behind the separation thesis: a historian should not be engaged in (present day) philosophical issues when interpreting

\footnotetext{
${ }^{5}$ See the webpage of the Cambridge Centre for Political Thought. I miss Istvan Hont's name from their list of the "founding fathers".

${ }^{6}$ For an overview, see for example Richter, 2003. The present author also published a volume of and about Cambridge-based intellectual historians, with an afterword (Hörcher, 1997).

${ }^{7}$ The Skinner essay which is referred to is Skinner, 1969.
} 
historical texts, as this would bring into his/her discussion the aforementioned "presentist commitments".

In perhaps the most widely read classical early essay of his, Skinner refers to his own efforts as an "alternative approach", which "would be more satisfactory as history". He goes as far as to talk about methodology, a mistake which he would not commit in a few years' time. In this groundbreaking essay he presents his point the following way: "...trying to make sense of past utterances does not mean to find the universally valid questions of it, which would seem to be directly relevant to answer our own problems: we must learn to do our own thinking for ourselves. It is by no means my conclusion, however, that because the philosophical value at present claimed for the history of ideas rests on a misconception, it must follow that the subject has no philosophical value in itself at all" (Skinner, 1969, p. 52).

In other words, Skinner, far from denying the political and philosophical relevance of the investigation of past thoughts, only denies a direct link between a historical approach and a universalist philosophical account of it. He does not deny, however, that one type of activity might be relevant for the other. What is more, he attributes an "indisputable value" to "studying the history of ideas", but in a cunning way: "[ $t$ ]o demand from the history of thought a solution to our own immediate problems is thus to commit not merely a methodological fallacy, but something like a moral error. But to learn from the past and we cannot otherwise learn it at all - the distinction between what is necessary and what is the product merely of our own contingent arrangements, is to learn the key to self-awareness itself" (Skinner, 1969, p. 53). This last claim amounts to the thesis that it is in fact through the separation of the two disciplines that intellectual history and political philosophy can become useful to each other. However, Skinner seems to leave it unclear how exactly he imagines this separation between them, while still preserving their relevance for each other. And the same is true of the other representatives of the orthodox Cambridge school history of political thought - much the same way as of Koselleck's Begriffsgeschichte, which is also very keen on a positivist self-definition.

\section{The Interplay between Intellectual History and Political Philosophy}

If you try to delineate the relationship of the two disciplines, you can argue the other way round to Skinner. You can say that the connection is impossible to cut off, as long as they have a common topic, namely political thought. Political philosophy and the history of political thought are only two perspectives on it, but these perspectives, looking at the same thing, necessarily will have overlaps. If you accept this starting point, the next step is to formulate the nature of these overlaps, and I suggest that there are two ways to do that, a weaker and a stronger form. According to the weaker form, a familiarity with the other discipline mutually fuels the practice of these disciplines. If you know the history of the concepts you use for your theoretical account of present political conditions, it will be much more realistic. And vice versa, if you know the (present) philosophical significance of political concepts, it will be much easier for you to make sense of their historical relevance, through a complete reversal of the teleology of what Herbert Butterfield called the Whig interpretation of history (Butterfield, 1931). 
But I will argue for a stronger claim of their interconnection: in this scheme one simply cannot make theoretical sense of present day politics (action) without giving an account of the conceptual framework (system of thought) that makes it possible and its evolution (past). More precisely: it is only by giving an account of the pragmatics of political thought (how concepts were used by actors in what circumstances with what purposes) that we shall be in a position to build up our own philosophical account about the present conditions, by understanding our own contexts in the action-field, and on the semantic field as well.

This stronger point about the necessary interplay of the two disciplines appears in the way of thinking of what I would call the second generation of Cambridge-influenced historians and also in the approach to their disciplines of political philosophers who also had a familiarity with the achievements of Cambridge. I have in mind as an example three representatives of this generation: István Hont, Raymond Geuss and Pierre Rosanvallon. ${ }^{8}$ They seem to me in the forefront of contemporary political thought, and all three are deeply influenced by a historical understanding of political ideas. Let me characterise the first two in a short form and introduce the third one as my key example this time. István Hont (1947-2013) was a Hungarian born, Cambridge-based historian of economic and political thought who was mostly interested in the Scottish Enlightenment and its ideas of the connections between political economy and real politics. Raymond Geuss (1946-) is a Cambridge-based Professor Emeritus in political philosophy and 19-20 ${ }^{\text {th }}$ century (mainly continental) philosophy, who brought to the forefront the discourse(s) of on political realism. Hont and Geuss must have had some influence on each other, the two of them organising the Cambridge Seminars in Political Thought and Intellectual History in 2007/8. The third of them is Pierre Rosanvallon (1948-), a French political theorist, whose ideas about the two disciplines will be analysed below. But the general claim is that the three of them represent a new way of scholarship focused on political thought, in which the historical and the contemporary are not barricaded from each other - on the contrary: they are put into interaction with each other. This is made easier by the fact that there is a natural disciplinary kinship between them, which makes their smooth operation into a very fruitful cooperation.

\section{Rosanvallon's Intellectual Family Tree}

In what follows, I would like to present some of the relevant ideas of the French political theorist, Pierre Rosanvallon, in order to show how in the work of this new generation the two fields are referred to each other. Certainly, this introduction will be unduly short and therefore sometimes distorting, but hopefully it can fulfil the function it is meant to serve. Also, the reader has to take into account the different disciplinary traditions in the English and French speaking worlds, both as far as their political realities and their pasts are concerned, and both as far as the political discourses (past and present) are con-

\footnotetext{
${ }^{8}$ Perhaps another example could be Richard Tuck, who was a younger colleague of the Skinner generation, a Cambridge-style historian of political ideas who was hired by Harvard University's Department of Government.
} 
cerned. ${ }^{9}$ But I hope that the issues that will be addressed here can indicate the direction the interdisciplinary practice of political thought may take in the discourse of this second generation. For brevity's sake, I shall concentrate on a single work by Rosanvallon, his notable "Inaugural Lecture" given on the occasion of winning the chair of the Collège de France (Rosanvallon, 2006). The speech was originally given in March 2002, and first published in French in 2003. In it the author provides a generative account of his own intellectual story, in the form of a kind of narrative, summing up the main phases and influences of his intellectual formation, and the main coordinates of his present position. ${ }^{10}$

It is instructive to collect first of all Rosanvallon's account of those scholars whom he regards as having exercised a major influence on his development. The list starts out with Marc Fumaroli, who is followed by François Furet, Claude Lefort, Paul Vignaux, and a little later by André Siegfried, Raymond Aron, Michel Foucault and Maurice Agulhon. There are obvious names on this list, including Fumaroli, Furet, Aron and Foucault. But Claude Lefort might be quite a surprise if we are not aware that besides being a political activist he was quite deeply involved in contemporary French philosophy, as well as in the history of political thought, publishing, for example, on Machiavelli ${ }^{11}$ (Lefort, 2012). But perhaps more importantly, his agitating leftist political convictions might have formed Rosanvallon's own activism, and for us even more significantly, his often pessimistic realistic views of politics might have a direct impact on Rosanvallon's own soberness. Another surprise appearance is that of Maurice Agulhon, who was himself a famous communist activist, who felt, however a strange adoration for President De Gaulle. From him, Rosanvallon might have taken over an interest in $19^{\text {th }}-20^{\text {th }}$ century French political thinking. Finally, Paul Vignaux, "the great late medievalist", as the speaker characterises him, joins this circle more for his active involvement in "democratic trade-unionism", a sort of activity which in France had quite a reputation in certain parts of the $20^{\text {th }}$ century, and less for his activity as a historian of late medieval philosophy.

Besides his contemporaries, Rosanvallon gives clues to his own way of thinking by mentioning some relevant French historians from the $19^{\text {th }}$ century as well: his favourites are Jules Michelet, Ernest Renan and Edgar Quinet. Let us shortly see why! Michelet is directly relevant for our present concern. In Rosanvallon's interpretation he made an effort "to illuminate the vicissitudes of the present by retracing the genesis of the French state and nation." This seems to be a direct inspiration for the reformed programme of the history of the political announced by Rosanvallon. Ernest Renan is more interesting for him as a kind of social critic, while Edgar Quinet appears in his narrative as an "ardent republican", who provides Rosanvallon with a very clear-cut judgement on the exhaustion of the intellectual resources of French democracy, which his follower seems to take quite seriously as a challenge. ${ }^{12}$

\footnotetext{
${ }^{9}$ One should certainly add here a third dimension: national or political cultural traditions also differ in their ways of relating political thought to action and action to thought, in other words - in their political pragmatics

${ }^{10}$ See also Rosanvallon, 2006b.

${ }^{11}$ Originally published in 1972.

12 "French democracy has exhausted its storehouse of ideas, which has to be stocked up again" (Rosanvallon, 2006, p. 34; quoting Quinet, 1868, vol. I, p. 11. The editor of the English translation adds here
} 


\section{Rosanvallon's Concept of the Political}

After presenting his direct and indirect intellectual fathers and forefathers, Rosanvallon offers a definition of the discipline he claims to practice, namely the history of "the political". He does not mention here in connection with this term the name of Carl Schmitt, who seems to be the fountain of this concept of "the political" in modernity (Schmitt, 1932), but in another essay, in another context he refers to "the martial celebration of a decisionism that burst the limits of the boredom of deliberation," mentioning Schmitt together with the name of Lenin ${ }^{13}$ (Rosanvallon, 2006c, p. 192). Also importantly, however, he does connect his own view of the political to a line of thought that runs from Hannah Arendt in the 1950s up to Claude Lefort in the 1970s, and further, reappropriating Schmitt's term and the term used in the realist discourses of international relations. In Rosanvallon's account, the political is both a field and a project. In the first sense, it is "what allows all of their (i.e. of the people's) activities and discourses to be understood in an overall framework" (Rosanvallon, 2006, p. 34). In other works, it seems to be a platform, he calls it a site, that secures the unity of individual actions and discursive acts. "As a project, the political means the process whereby a human collectivity, which is never to be understood as a simple 'population', progressively takes on the face of an actual community" (Rosanvallon, 2006, p. 34). At this point, when we try to make sense of Rosanvallon's concept of the political, it needs to be stressed that the question of the community seems to be a real problem for him, which is in itself a criticism of mainstream liberal theory (as we shall see, he is critical of both Rawls and Habermas). He seems to be really aware of "the recurrent difficulty of forging a nation founded on the recognition of shared obligation" (Rosanvallon, 2006, p. 35). But it is not simply "collective action" that is involved in this concept. It is critical of the apolitical politics of liberalism, which concentrates on institutional arrangements. Rosanvallon finds more interesting the "contradictions and ambiguities" that run through our modern democracies. And in understanding the road which led to the particular deadlocks we encounter, Rosanvallon turns to the past of our present thoughts to make sense of them, and to the past actions that forged our present framework of mind and action. ${ }^{14}$ While in its actual unfolding, the history (in his case of French democracy) was nothing but a "thread of trial and error, of conflict and controversy," and if we forgot about that we would not be able to confront our own present situation, which is overdetermined by these past struggles. "History conceived in this way is the active laboratory that created our present and not simply its background" (Rosanvallon, 2006, p. 39). It is here that he turns towards a more elaborate explanation of

a quote of Rosanvallon in an issue of Le Monde: "Il faut refaire le bagage d'idées de la démocratie française" (Rosanvallon, 2002).

${ }^{13}$ In a footnote he adds: "The fact that these authors have recently been celebrated in common would repay closer scrutiny" (Rosanvallon, 2006c, p. 276, n5). The reference might aim at present day leftist enthusiasts of Schmitt, including Chantal Mouffe and for example Bolsinger (2001). Schmitt's new supporters inspired a renewed interest in political realism and international theory. See for example Bellamy, Baehr, 1993. But one should also refer here to Raymond Geuss, who took Lenin on board for serious reflection.

${ }^{14}$ At one point he quotes Marc Bloch: "Misunderstanding of the present is the inevitable consequence of ignorance of the past" (Bloch, 1964, p. 43). 
what he means by his practice of the history of the political. He extrapolates from all these a "permanent dialogue between present and past" (Rosanvallon, 2006, p. 39) and that is what he is interested in.

\section{The History of the Political}

This history of the political is both characterised by "the passionate concern for [present, F. H.] relevance and a scrupulous attention to history" (Rosanvallon, 2006, p. 39). And although it has this pillar of presentism, it is opposed to "political philosophy" - we shall later see why.

But first it is contrasted with the history of politics. In spite of all his efforts to describe the difference, however, between the two, it remains only vaguely described. We only learn that he wants to include the analyses of passions and interest in his research programme, and most of all, of what he calls here "the enigma of the political" (Rosanvallon, 2006, p. 40). Perhaps it takes us a bit further if we have a look at the disciplines from which he wants to distinguish his own scholarly activity, namely social history, political sociology, political theory and finally intellectual history. By drawing the borders of his discipline along these lines, he also marks out the neighbouring territories - these are the fields which the history of the political verges upon. Let us have a short overview of how he describes the differences between them and the history of the political.

While social history, too, deals with "the interpretation of conflicts of power and oppositions of interest" it has the drawback, however, that it "takes only a portion of reality into account" (Rosanvallon, 2006, p. 40). His example is universal suffrage, which cannot be understood simply as a class conflict, as the "internal" history of the question needs further elaboration. Sociology and especially political sociology "'unmasks' the way power is arrogated," however, it understands social reality in structural terms, which makes it ponderous and inflexible, providing a simultaneous view of affairs without making visible the dynamics of the affairs. As for political theory, it is here that Rosanvallon tries to illuminate how he positions himself in comparison with Rawls and Habermas. While he accepts that these authors were in the forefront of the "renovation of political thought, which brought with it in the 1970s a 'return of the political'." mainly criticises these influential political philosophers' "essentially procedural concerns" (instead of their concentrating on "the complexity of reality") and detects that "[r]eason is available in this framework only on condition of abstraction, according to the extent distance is won from the sound and fury of the world" (Rosanvallon, 2006, p. 44).

The final distinction concerns intellectual history, this way making it explicit that Rosanvallon's own discipline is not to be identified either with political philosophy or the

\footnotetext{
${ }^{15}$ Rawls published his opus magnum in 1971, while Habermas's Habilitationsschrift about the birth of an independent public sphere was published already in 1962, and his breakthrough came with his 1981 piece with the theory of communicative acts. To Rosanvallon's sketchy narrative of a renewed interest in political theory one should certainly add that the rebirth was not independent of an interest in the history of political thought, as Peter Laslett's series of Philosophy, Politics and Society (first published in 1958) indicated.
} 
history of political thought. Although the source materials of the two historical disciplines are the same, in the history of the political they are not investigated in isolation from the other parts of a past reality, as he supposes in the case of the history of political thought, on the contrary, "these representations are understood as real and powerful 'infrastructures' in the life of societies" (Rosanvallon, 2006, p. 45). He takes the key formula this time from Michel de Certeau, the French Jesuit thinker, and relying on that claims himself that "[n]arratives and representations have precisely this positive function of opening "a legitimate theatre for practical actions"16 (Rosanvallon, 2006, p. 46). His aim, as earlier in the history of mentalities, is nothing less than "the totality of the elements that compose that complex object that a political culture is" (Rosanvallon, 2006, p. 46).

\section{To Theorise the Contingencies of Democracies}

Besides focusing on the political in a historical manner, Rosanvallon's novelty consists of his emphasis on the contingent nature of democracies in another sense, too. Instead of writing a Whiggish history of democracy's overall success, he repeats his insistence that what is required is nothing less than the "examination of the disappointments and the disarray to which it can lead" (Rosanvallon, 2006, p. 46). He is not looking at democratic history as a march of victory, but one full of conflicts, agonising tensions and unresolvable aporias. One of its inner contradictions concerns its temporal dimension. The starting point is of course the famous debate of Burke and Paine, where he seems to accept Paine's conviction that no generation should be excluded to determine its own fate by an earlier social pact of the forefathers. The exaggeration of the point is evident from Rosanvallon's reliance on Marx when explaining it, who regards the tradition of "dead generations" a "nightmare on the brain of the living" (Rosanvallon, 2006, p. 48). He himself is less extreme, as he seems to include in his own view a traditionalist vein with the gesture of "the nation linking memory to the promise of a shared future" (Rosanvallon, 2006, p. 49). More importantly, the real temporal tension within democratic theory, in his view, is the one between the short term and long term perspective. One is reflecting on what Renan called "the caprice of the moment," while the other is implied, for example, by the ideal of the rule of law, which does not allow rapid changes within the framework of the political.

There is a further dimension of democratic indeterminacy in Rosanvallon's professional credo: the permanent crisis of political language. In his often passion-driven, colourful style he describes "the drama of language's breakdown." In his interpretation, one of the battlegrounds of the French Revolution was language. He seems to be fully convinced by Condorcet claiming that "the alteration of the meaning of words indicates the alteration of things" ${ }^{\prime 17}$ (Rosanvallon, 2006, p. 50). Following in the footsteps of critical theory, Rosanvallon recovers the linguistic aspirations of the revolutionaries, which amounted to an exclusion of contradictions from reality, and adds that poets and novel

\footnotetext{
${ }^{16}$ Quote from Certeau, 1984, p. 125.

${ }^{17}$ Quote from de Condorcet 1793, p. 10.
} 
writers could "remain open to the contradictions of the world" (Rosanvallon, 2006, p. 50-51).

These contradictions implied by Rosanvallon in his description of his own discipline present the history of the political as "a history of aporias, then, but also a history of limits and boundaries" (Rosanvallon, 2006, p. 51). But it is exactly here, at the moment of experiencing the fragility of the historical venture it scrutinises that this discipline can turn into a philosophically sound enterprise. For it is indeed by returning to earlier phases of the adventure, always re-examining its intellectual presuppositions and its accidental activities that it can gain the sort of self-knowledge that is required when confronting the challenges of the moment. If Western philosophy since Socrates is nothing more than the thinker's learning his/her self-limitations and boundaries, to build up a philosophical account of democratic politics requires the same sort of self-scrutiny from the scholar who is admittedly involved in the fate of his/her political community. A historical investigation which is executed with an awareness of the dilemmas of the day in one's mind this way really connects present significance with a clarification of the past.

The way Rosanvallon illustrates this overlap of the temporal dimensions is by reference to totalitarianism, as interpreted by thinkers of the political, like Arendt and Lefort. He claims that one cannot recognise the novelty of this form of power without having understood its manifestations "as deviant forms of democratic modernity" (Rosanvallon, 2006, p. 51). It gained its control over the minds of the people by being presented as the superlative form of democracy, its political engine, the party, not only representing the population, but identified with "the very substance of the people" (Rosanvallon, 2006, p. 52).

Rosanvallon's account of the totalitarian exaggeration of democratic unity is only one extreme of the use of politics and the political to discredit democracy. The other extreme of a corrupted democracy is the post-1989 scenario, where national awakening leads to a number of national splits, resulting in absurd situations where "existing populations have simply refused to coexist any longer" (Rosanvallon, 2006, p. 53). It is here that we return to the communitarian or republican component of Rosanvallon's message: he seems to be engaged in an understanding of the polity according to which nation states should remain the sole trustees of democratic sovereignty.

These diagnoses of the risks of (not only, but paradigmatically the history of French) democracy seem to be well founded. It is also understandable why Rosanvallon is keen to return to these problem-fields: his "continuous history of democratic disappointment" is meant not simply as a positive science practiced in a Comte-like fashion, or an antiquarian interest in the past, as represented by strict historicists. He envisages his own discipline as a form of involvement in the affairs of the public (res publica), joining in this respect Michelet, who famously claimed: "[i]t is not really teaching that occurs here, to be perfectly precise. It is the examination of high questions, in front of the public" $" 18$ (Rosanvallon, 2006, p. 58). If so, this history should not present an unbending vector line of the Whiggish form of historical teleology glorifying the present in a Hegelian way. For it is the zigzags, the leaps and the discrepancies in the rhythm and mel-

${ }^{18}$ Quote from Michelet, 1995, p. 20. 
ody of the concert of political ideas and actions that are more interesting than their harmonic unison.

\section{Conclusion}

This paper recaptured the way the discipline of the history of the political was introduced by Pierre Rosanvallon, one of the key protagonists in French political theory in his influential "Inaugural Lecture" at the Collège de France. His views of his own profession were taken as an example representing a more collaborative effort between the history of political thought and political theory than was admitted by orthodox historians of political thought, mainly, but not exclusively, of the Cambridge school. While Cambridge style intellectual history was meant to be practiced with a blind eye towards the present moment (of politics), the history of the political turns towards the past in order to get a more detailed and historically substantiated, and therefore more precise view of the present. It showed that relying on a number of forerunners in French intellectual life, Rosanvallon took the concept of "the political", which he used as a more dynamic and agent-oriented notion of public life than politics, and built on it a whole discipline, which he distinguished from (and in this way also connected to) social history, political sociology, political theory and intellectual history. If this summary could show that there is a logical possibility for this sort of consortium between the history of political thought and political philosophy, it has achieved its aim.

There are two more things to add to this story. One is that a rigid opposition between Skinner's and Rosanvallon's relevant positions should not be assumed. For in spite of all his efforts to show the political neutrality of the historian, Skinner himself stepped out of the shadow of history when he presented his own ideal political type: a kind of republicanism that was meant to be suitable for the conditions of our present. Certainly he could only do this by developing two separate intellectual identities: one remained within the confines of professional history-writing, while the other became innovative and daring, looking for resources in the past to meet the political demands of the moment. ${ }^{19}$ And most of the other Cambridge people followed suit. John Dunn wrote a huge monograph on the fate of democracy (Dunn, 1992), becoming himself a strong critical voice of democratic theory; John Pocock turned out to be a New Zealand local patriot (Pocock, 2005), Richard Tuck almost an expert in international relations and issues of contemporary political economy (Tuck, 2008). To make this happy ending even more pronounced, we should add that the second generation Cambridge people, like Geuss and Hont, themselves at the very beginning already professionally interested in the politics of their own time, raised their own disciples (including people like Isaac Nakhimovsky, Duncan Kelly and Bela Kapossy), who embody a new model of expertise in political realism and international relations which is based on a solid basis of acquaintance with the subtleties of the history of political thought.

\footnotetext{
${ }^{19}$ The usual references for this innovative side of Skinner are Skinner, 1997 and Skinner, 2002.
} 


\section{Bibliography}

Aristotle (1895), Poetics, trans. Butcher, S. H., Macmillan, London.

Bellamy R., Baehr P. (1993), Carl Schmitt and the Crisis of Liberal Democracy, "European Journal of Political Research", 23, p. 163-85.

Bloch M. (1964), The Historian's Craft, Vintage, New York

Bolsinger E. (2001), The Autonomy of the Political: Carl Schmitt's and Lenin's Political Realism, Greenwood Press, London.

Butterfield H. (1931), The Whig Interpretation of History, G. Bell, London.

Cambridge Centre for Political Thought, http://www.polthought.cam.ac.uk/, 10.02.2015.

Certeau M. (1984), The Practice of Everyday Lufe, University of California, Berkeley.

Collini S., Winch D., Burrow J. (1983), That Noble Science of Politics: a Study in Nineteenth-Century Intellectual History, Cambridge University Press, Cambridge.

de Condorcet M. (1793), Sur le sens do mot révolutionnaire, "Journal d'instruction sociale" 1, June 1.

Dunn J. (1992), Democracy: The Unifinished Journey, 508 B.C. to A.D. 1993., Oxford University Press, Oxford.

Floyd J., Stears M. (2011), Political Philosophy versus History? Contextualism and Real Politics in Contemporary Political Thought, Cambridge University Press, Cambridge.

Hörcher F. (1997), A koramodern politikai eszmetörténet cambridge-i látképe (The Cambridge view of early modern political thought), in: F. Hörcher, A koramodern politikai eszmetörténet cambridge-i látképe, "Tanulmány Kiadó, Pécs", p. 287-306.

Iggers G. G. (2011), The Intellectual Foundations of Nineteenth-Century "Scientific" History: The German Model, in: The Oxford History of Historical Writing, eds. S. Macintyre, J. Maiguashca,

A. Pók, Oxford University Press, Oxford, p. 41-58.

Iggers G. G. (1983), The German Conception of History: The National Tradition of Historical Thought from Herder to the Present, $2^{\text {nd }}$ rev. edn., Wesley an University Press, Middletown, Ct.

Lefort C. (2012), Machiavelli in the Making, Northwestern University Press, Evanston, Ill.

Michelet J. (1995), Cours au Collège de France, vol. 1: 1838-1844, Gallimard, Paris.

Moyn S. (2006), Introduction. Antitotalitarianism and After, in: Rosanvallon P : Democracy Past and future, ed. S. Moyn, Columbia University Press, New York, p. 1-28.

Quinet E. (1868), Critique de la Revolution, reprint in Quinet E., "La revolution", $5^{\text {th }}$ ed., 2 vol., Paris.

Pocock J. G. A. (2005), The Discovery of Islands: Essays in British History, Cambridge University Press, Cambridge.

Reill P. H. (1975), The German Enlightenment and the Rise of Historicism, University of California Press, Berkeley.

Richter M. (2003), A Lexicon of European Political and Legal Concepts: A Comparison of Begriffsgeschichte and the 'Cambridge School' "Critical Review of Social and Political Philosophy", vol. 6 , p. 91-120.

Rosanvallon P. (2002), "Il faut refaire le bagage d'idées de la démocratie française" Entretien avec ce professeur au Collège de France et président de l'association La République des idées, "Le Monde", November 21, http://olivier.hammam.free.fr/actualites/documents/reacs/monde.htm\#REACMOND02, 10.02.2015.

Rosanvallon P. (2006), Inaugural Lecture, Collège de France, in: Rosanvallon P.: Democracy Past and Future, ed. S. Moyn, Columbia University Press, New York, p. 31-58.

Rosanvallon P. (2006b), Toward a Philosophical History of the Political, in: Rosanvallon P: Democracy Past and Future, ed. S. Moyn, Columbia University Press, New York, p. 59-76.

Rosanvallon P. (2006c), From the Past to the Future of Democracy, in: Pierre Rosanvallon:-Democracy Past and Future, ed. S. Moyn, Columbia University Press, New York, p. 189-217. 
Schmitt C. (1932), Der Begriff des Politischen, revised version, Duncker und Humblot, Berlin.

Skinner Q. (1969), Meaning and Understanding in the History of Ideas, "History and Theory", vol. 8, no 1, p. 3-53.

Skinner Q. (1997), Liberty before Liberalism, Cambridge University Press, Cambridge.

Skinner Q. (2002), A Third Concept of Liberty, "Proceedings of the British Academy", vol. 117. p. 237-68.

Tuck R. (2008), Free Riding, Harvard University Press, Cambridge-London.

\section{Skinner i Rosanvallon: pojednanie historii myśli politycznej i filozofii politycznej}

\section{Streszczenie}

Artykuł podejmuje zagadnienie czy właściwa historia myśli politycznej powinna wystrzegać się wszelkiego kontaktu z poważną filozofią polityczna, którego to stanowiska żarliwie bronili wcześniej historycy myśli politycznej z Cambridge, czy też nie. Przedstawiono tu pogląd, że silna stronniczość w dziedzinie polityki czy filozofii może zniszczyć wiarygodność miarodajnej historii myśli politycznej, ale uprawiając tę naukę z definicji nie sposób uchronić się przed rozważaniami polityczno-filozoficznymi. Artykuł próbuje także wykazać związek filozofii politycznej z historią myśli politycznej i vice versa. Artykuł szczególnie koncentruje się na następujących dwóch twierdzeniach: a) wszelka rekonstrukcja historii myśli politycznej pozbawiona własnej pozycji polityczno-filozoficznej jest nieokreślona i dlatego nie stanowi źródła wiedzy, b) bez przyjirzenia się historii myśli politycznej filozofia polityczna jest ślepa, wyobcowana, nieuzasadniona teoretycznie, a tym samym nawet potencjalnie niebezpieczna.

$\mathrm{Z}$ metodologicznego punktu widzenia $\mathrm{w}$ artykule podjęto próbę ponownego ujęcia niektórych wniosków z rozważań na temat związku obu dyscyplin, ze szczególnym uwzględnieniem kontekstu francuskiego i angielskiego (a konkretnie dzieł Rosanvallona i Skinnera).

Słowa kluczowe: historia myśli politycznej, filozofia polityczna, Rosanvallon, Skinner, szkoła Cambridge 
